\title{
Change and Stability in Parent-Child Contact in Five Western Countries
}

\author{
Matthijs Kalmijn · Jannes De Vries
}

Received: 2 June 2008/Accepted: 21 November 2008/Published online: 20 December 2008

(C) The Author(s) 2008. This article is published with open access at Springerlink.com

\begin{abstract}
Although much is known about changes in the conjugal family, little is known about trends in contact between parents and adult (independently living) children. Using unique survey data, we study changes in contact with the mother and the father in five western countries over a 15-year period (Austria, West Germany, Great Britain, the United States, and Italy). We describe changes and we examine the role of compositional changes in the trend. We find no evidence for a decline in intergenerational contact, in contrast to notions of individualism. In two countries, there has been an increase in contact with the mother and in three countries no net trend is observed. Contact with the father has not changed. Other forms of contact (e.g., telephone contact) have increased. Some compositional changes have had a downward pressure on the trend, leading to a decline in contact (i.e., rising education, declining church attendance), but these pressures have been compensated by counteracting compositional changes (declining sibsize) and by behavioral changes.
\end{abstract}

Keywords Family change - Intergenerational relations · Individualization · Trends · Parent-child contact

Résumé Alors que beaucoup de connaissances ont été accumulées sur la famille conjugale, on dispose de peu d'éclairage sur l'évolution de la fréquence des contacts entre parents et enfants adultes noncohabitants. A l'aide de données d'enquête tout à fait uniques, cette étude explore la fréquence des contacts avec la mère et avec le père dans cinq pays occidentaux, sur une période de 15 ans. Les changements sont décrits, de même que le rôle joué par les évolutions de la composition de la

\footnotetext{
M. Kalmijn ( $\square)$

Department of Sociology, Tilburg University, P.O. Box 90153, 5000 LE Tilburg, The Netherlands e-mail: m.kalmijn@uvt.nl

J. De Vries

Statistics Netherlands, Kloosterweg 1, 6412 CN Heerlen, The Netherlands
} 
population dans ceux-ci. Aucun recul des contacts entre générations n'est mis en évidence, contrairement à ce que les notions d'individualisme pourraient laissent supposer. Dans deux des pays, on observe une hausse des contacts avec la mère, et dans trois autres, aucune tendance nette n'émerge. La fréquence des contacts avec le père n'a pas varié. D'autres formes de contacts (par exemple, les contacts téléphoniques) sont en augmentation. Certains facteurs de composition ont eu un effet à la baisse sur les contacts (par exemple, la hausse du niveau d'instruction, le déclin de la pratique religieuse), mais ces effets ont été compensés par des facteurs ayant des conséquences inverses (réduction de la taille des fratries) et par des changements de comportements.

Mots-clés Changement familial · Relations intergénérationnelles ·

Individualisation $\cdot$ Tendances $\cdot$ Contacts parents-enfants

\section{Introduction}

Trends in marriage and family life in the western world have been documented extensively. In many countries, marriage and fertility rates have declined, divorce rates have increased, and unmarried cohabitation has become more common. In addition, the division of paid and domestic labor in marriage has become more egalitarian, relations between parents and children have become less authoritarian, and spouses have gained more privacy and autonomy in marriage. These developments have been linked to major societal changes such as the rising economic independence of women, the expansion of higher education, the declining influence of the church, and the spread of modern individualistic values (Blossfeld 1995; Cherlin 1992; Lesthaeghe 1983).

Much less is known about trends in the relationships between parents and adult children. Have changes in the conjugal family been accompanied by changes in the extended family? If marriage has become more fragile and people have become more independent from the conjugal family, does this imply that intergenerational relations have become weaker as well? As we will discuss shortly, there are a number of reasons to expect such a development, but there are also counterarguments, suggesting that intergenerational bonds have become more rather than less important over time. Theoretically, it is not so clear what to expect and empirically, descriptive information on trends is lacking.

A few studies have examined period changes in parent-child contact. A comparison of cross-sectional studies of elderly parents in Switzerland in 1979 and 1994 showed increases in weekly visiting of family members (Vollenwyder et al. 2002). A study of the Netherlands compares elderly in 1992 and 2002 and finds a small decline in contact frequency with the children and a substantial increase in support exchange (Van der Pas et al. 2007). A comparison of two nationally representative surveys from Belgium shows a decline in weekly visits from nonresident children between 1985 and 2001 (Vanderleyden and Vandenboer 2003). Finally, a comparison of three national surveys in Great Britain shows that the percentage of parents who see their child at least weekly declined from 1986 to 
1999 (Murphy 2004). There are also studies examining changes in coresidence of adult children with (elderly) parents (Ruggles 2007; Tomassini et al. 2004a; Wolf 1995), but this more indirectly relates to the issue of parent-child contact.

An important reason why so little is known about trends in parent-child contact is that few repeated cross-sectional surveys have included questions on this issue. In this paper, we describe changes in contact between adult children and parents by analyzing nationally representative data from the International Social Survey Programme (ISSP). In the 1986 and 2001 waves of the ISSP, identical questions about parent-child contact were asked, and these questions were asked separately for the father and the mother and separately for face-to-face contact and telephone contact. The countries that participated in both waves were Austria, West Germany, Great Britain, the United States, and Italy. Our research questions are as follows: To what extent have there been changes in parent-child contact between 1986 and 2001? To what extent are these changes due to changes in the social composition of the population? The focus here is on changes in education, women's work, family size, religion, and marital status, all pertaining to the children's generation. Finally, to what extent are the trends we observe similar or different in the five countries we study?

Before we continue, we note that intergenerational contact does not necessarily coincide with the perceived quality of the intergenerational tie (Silverstein and Bengtson 1997). There are several reasons for this. First, contact is also motivated by a normative obligation to have contact (Rossi and Rossi 1990). When there are strong normative obligations, contact will be frequent in poor relations and this will reduce the correlation between quality and contact. Second, people in very good relationships may have infrequent contact due to restrictions, for example, because they live far away from each other. It is also true, however, that there is a positivealbeit modest - correlation between the perceived quality of the relationship and the frequency of face-to-face contact (Kalmijn and Dykstra 2006). Moreover, there is a strong positive relationship between contact frequency and intergenerational support exchange (Silverstein et al. 1995). Support to parents often requires contact and when there is frequent contact, children and parents will be more aware of each other's needs, which in turn will increase intergenerational support. For these reasons, contact remains an important and often studied dimension of the intergenerational relationship (Lye 1996).

\section{Background and Hypotheses}

In analyzing social trends, it is useful to make a distinction between behavioral and compositional changes. With compositional changes, we refer to changes in the composition of the population with respect to characteristics that have an influence on intergenerational contact. Because the composition of the population changes over time, this can lead to a change (a decline or increase) in intergenerational contact. With behavioral changes, we refer to changes in intergenerational contact of persons after holding constant changes in population composition. Below, we start with compositional explanations. We also discuss the role of coresidence, but 
we will do this in a separate section. In the last paragraph, we speculate on possible differences among countries in the trends that we predict. In most of our hypotheses, face-to-face contact and telephone contact are considered simultaneously. In some cases, there are theoretical reasons to formulate different hypotheses for these two types of contact (Van Gaalen and Dykstra 2006).

A first important change in most western societies is the increase in women's labor force participation. Since women most often maintain family ties (Hagestad 1986), increasing female labor force participation could in principle lead to a decline in intergenerational contact. Research confirms that children's time budget serves as a restriction for contact with and support to parents, especially for face-toface contact, but there is not much evidence that women's work reduces intergenerational contact (Kalmijn and Saraceno 2008; Klein Ikkink et al. 1999; Spitze and Logan 1991; Waite and Harrison 1992). We test this hypothesis again and formulate our hypothesis in two steps: Women's work has a negative effect on contact with parents (H1a), and given that this is true, The increase in the number of women who work for pay leads to a decrease in contact with parents $(\mathrm{H} 1 \mathrm{~b})$.

Another important change is secularization. Secularization has played an important role in changing family life, in particular for understanding rising divorce and cohabitation rates and declining family size (Lesthaeghe 1983; Van de Kaa 1987). Because people who attend church have more traditional values about marriage and family issues than those who do not, it can be expected that church attendance is also positively related to intergenerational contact (Daatland and Herlofson 2003; Killian and Ganong 2002). Our hypothesis is: Church attendance has a positive effect on contact with parents $(\mathrm{H} 2 \mathrm{a})$, and The decrease in the number of people who regularly attend church leads to a decrease in contact with parents (H2b).

The expansion of higher education will also have played a role in trends in intergenerational contact. Many studies have shown that the higher educated have less frequent contact with their parents than the lower educated (Grundy and Shelton 2001; Kalmijn 2006). Part of this effect is due to the fact that higher educated children live further away from their parents than lower educated children (Kalmijn 2006; Shelton and Grundy 2000). Effects of education on telephone contact are often positive, suggesting that-due to geographic constraints- the higher educated compensate lower face-to-face contact in part with more telephone contact (Kalmijn 2006). We formulate separate hypotheses for the two forms of contact. Education has a negative effect on face-to-face contact $(\mathrm{H} 3 \mathrm{a})$, and The increase in the level of education of the population leads to a decrease in face-to-face contact with parents (H3b). For telephone contact, we predict the opposite: Education has a positive effect on telephone contact $(\mathrm{H} 3 \mathrm{c})$ and The increase in the level of education of the population leads to an increase in telephone contact with parents $(\mathrm{H} 3 \mathrm{~d})$.

A trend which may have played a different role is the decline in family size. Respondents on average will have fewer siblings now than in the past and this may affect the relationship they have with their parents. Parents will need less help of each individual child when they have more children so that, at the dyad level, support and contact may decline with family size (Spitze and Logan 1991). All studies that use dyads (or children) as the unit of analysis find that the more siblings 
a child has, the less often the child visits the parent and the less often he or she gives support to the parent (Kalmijn and Saraceno 2008; Spitze and Logan 1991). Note that this does not mean that parents in larger families get less help or receive fewer visits-lower levels at the dyad level are compensated by larger numbers of children (Kalmijn and Dykstra 2006; Spitze and Logan 1989). We analyze data from the perspective of children and thus expect that Sibsize has a negative effect on contact with parents $(\mathrm{H} 4 \mathrm{a})$ and that The decline in sibsize leads to an increase in contact with parents $(\mathrm{H} 4 \mathrm{~b})$.

Another compositional hypothesis focuses on the role of parental divorce. The data we use do not include a measure of parental divorce, but it is nevertheless important to mention this hypothesis. As is well known, a parental divorce has a strong negative effect on relationships between fathers and adult children. Evidence for a negative effect on contact frequency with fathers has been presented for several different countries (Aquilino 1994; Cooney and Uhlenberg 1990; Szydlik 1996; Grundy and Shelton 2001; De Graaf and Fokkema 2007; Tomassini et al. 2004b). Effects of parental divorce on contact with the mother are generally small (Kalmijn 2008). Given the increase in divorce in the western world, one would expect a compositional effect. Our hypothesis is: A parental divorce has a negative effect on contact with fathers ( $\mathrm{H} 5 \mathrm{a})$, and The increase in divorce leads to a decline in contact with fathers (H5b). Since we will not be able to test this hypothesis, this is a residual compositional change that will emerge technically as a behavioral change.

The marital status of the child may also be of some importance. Some studies have shown that married children have less frequent contact with their parents than single children (Sarkisian and Gerstel 2008). An explanation is that single children have more time to see their parent and have more need to have contact with people to whom they feel close. Because the share of married (or cohabiting) respondents has declined over time, this could also have an effect on the trend. We expect that Children who are married have less contact with their parents than single children (H6a), and The decline in the percentage of married persons leads to an increase in contact (H6b).

To what extent will there be changes after these compositional changes have been taken into account? The literature suggests competing hypotheses. A first argument has to do with filial norms, i.e., normative obligations toward parents (Burr and Mutchler 1999; Rossi and Rossi 1990; Stein et al. 1998). Just like other traditional family norms (Lesthaeghe and Meekers 1986; Thornton and YoungDeMarco 2001), filial norms have become weaker over time (Gans and Silverstein 2006). This would imply that the basis of contact with parents has shifted from obligation to choice (Lye 1996). In theory, this can lead to a decline in contact because normatively prescribed contact in poor relationships will occur less often. The normative perspective of parents may have changed as well. The traditional norm that older adults can rely on their adult children as sources of support and care in case of need has been gradually replaced by the norm that one should be independent and autonomous of one's children. Studies have shown that many elderly persons express a desire to remain independent as long as possible and to not be a burden to their children, even if and when they become frail (Silverstein and Bengtson 1994). 
Against the notion of decline, some authors have argued that multigenerational linkages have become more rather than less important over time (Bengtson 2001; Bengtson et al. 2002; Bonvalet 2003). First, due to the increased life expectancy, parents and adult children share more time together which would make it more important for both parents and children to invest in their relationship. Second, the declining number of children in society may have increased the importance of each child for parents. In part, this is a compositional effect due to declining family size, but it is possible that children in society at large have become more central now that fertility rates are low. In a sense, when children are scarce, their 'value' may increase. Third, the increasing demand for child care has made parents more important for children in their role as grandparents taking care of their children's children (Oppelaar and Dykstra 2005; Silverstein and Marenco 2001). Fourth, technological changes have made contact more feasible. Modern means of transport have increasingly become universal in most societies, telephones have become ubiquitous, and new means of communication have emerged (mobile phone, email, sms). This has resulted in more frequent contact with others, including parents.

A different issue to consider is the role of coresidence. In the mid-1980s, the percentage of adult respondents (with a living mother) who live with their mother varies between $10 \%$ in the United States to about $30 \%$ in Italy (Höllinger and Haller 1990). More importantly, there has been a decline in adult-child coresidence over time (Grundy 2000; Ruggles 2007; Shelton and Grundy 2000; Van der Pas et al. 2007). How this change has affected contact is a difficult question. If coresidence is considered as daily contact, the decline in coresidence will by definition lead to a decline in contact. If one focuses on resident children only, however, the trend implication is not clear. Whether it will lead to an increase or decrease in contact between nonresident children and their parents will depend on what type of parentchild ties-especially the good ties, or perhaps the poor ties-have contributed most to the period increase in independent living.

Finally, we analyze whether trends will be similar or different in the five countries we examine. Our paper will not test hypotheses about country differences - the number of countries is too small for that purpose-but we can provide some speculations. Some countries are more familialistic in their orientation than other countries. If we use indicators such as family contact, family support, and intergenerational coresidence, Southern European countries are believed to be more familialistic than Northern European countries and German speaking countries are somewhat more familialistic than the United States and possibly Great Britain as well (Börsch-Supan et al. 2005; Höllinger and Haller 1990; Kalmijn and Saraceno 2008; Murphy 2004; Reher 1998; Tomassini et al. 2004b). What this implies for trends is not directly clear. It may be that more familialistic countries are more resistant to trends than less familialistic countries, but one can also argue that there is more room for decline when contact is very frequent. A different speculation is that countries which have modernized and developed earlier than others, will show less change in the period we consider than countries which have experienced cultural and economic changes more recently. This could imply more change in more traditional countries (e.g., Italy) than in more modernized countries (e.g., United States). 


\section{Data, Measurement, and Design}

\subsection{Data}

We use data from the International Social Survey Programme (ISSP). In the 1986 and 2001 waves of the ISSP, a special module on social relationships was fielded. This module was based on a proposal developed by Max Haller. Earlier analyses of the first wave of these data can be found in Höllinger and Haller (1990) and Murphy (2004). ${ }^{1}$ We analyze changes in the countries which participated in both waves: West Germany, Great Britain, the United States, Austria, and Italy. ${ }^{2}$ Because the samples of West Germany, Great Britain, and the United States are not completely representative with respect to sex and age, we weight the data to adjust for this. In most cases, the surveys were face-to-face interview surveys but the module on social relationships was a self-completion booklet which was handed out after the interview. The fieldwork methods in the two waves were more or less similar and the questionnaire was also similar. From the data, we select respondents aged 18-70 with at least one living parent. The sample sizes are not large enough for analyzing changes in specific age groups.

Although the data provide one of the few sources of information on change in parent-child contact in multiple countries, they also have limitations. Most importantly, while much information is available on the children's generation (the respondents), less is known about the parents. For example, we know whether or not the parent was widowed, but there is no information on the parents' divorce, the parents' health status, or their ages, all of which will affect contact (Grundy 2005; Lawton et al. 1994; Silverstein et al. 1995). Missing information on parental divorce makes it more difficult to explain trends in father-child contact. Parental divorce has only a weak impact on contact with the mother (Kalmijn 2008), so that this omission is less problematic for trends in mother-child contact.

\subsection{Measurement}

Two questions were asked about contact: "How often do you see or visit your mother?" and "How often do you have any other contact with your mother besides visiting, either by telephone or letter?" The same questions were asked for the father. In 2001, e-mail and fax were added to the question about other contact. Since no one will have had an Internet connection at home in 1986, we believe that the change in question wording will not affect the outcomes of the comparisons.

The answering categories were: daily, several times a week, at least once a week, at least once a month, several times a year, and less often. In 2001, the category 'never' was added. We combined this category with the category 'less often' to

\footnotetext{
${ }^{1}$ We have not been able to find previously published research articles on changes in parent-child contact with the ISSP data (using Web of Science and Sociological Abstracts).

${ }^{2}$ In 2001, Germany participated but our analyses focus on the former West Germany. Hungary was also included in both years but we focus on western societies in this paper. Furthermore, Australia was surveyed in both 1987 and 2001, but we excluded Australia due to a problem with the design of the 2001 questionnaire.
} 
make things comparable. We recoded the categories to the approximate number of contacts per year. Because the resulting variable is skewed, we took the natural logarithm (cf. Waite and Harrison 1992). This also facilitates the interpretation of the coefficients. More specifically, $\left(e^{\mathrm{b}}-1\right) \times 100$ can be interpreted as the percentage change in the number of contacts per unit increase in the independent variable. In the case of a dummy-variable, $\left(e^{\mathrm{b}}-1\right) \times 100$ is equal to the percentage difference in the number of contacts between the groups. An important advantage of this transformation is that it makes the measure relative. Hence, the difference between 41 and 52 contacts is given less weight than the difference between 1 and 12 contacts. This seems intuitively plausible.

We use the following variables to test our compositional hypotheses:

(a) Paid employment of the respondent (this contrasts those with paid work with all others). We include this variable in interaction with the sex of the respondent because primarily women's employment will affect contact with parents.

(b) Church attendance of the respondent (once a month or more often is contrasted with less often).

(c) Education of the respondent (based on a question about the number of years that the respondent was in school).

(d) The number of (living) siblings of the respondent.

(e) Marital status of the respondent (contrasting married/cohabiting with single).

We use several control variables in the models: whether the parent is widowed, the age of the respondent, and the sex of the respondent. Geographic distance is not included as a control variable, although travel time was included in the data. Distance has a very strong relationship with contact frequency but the causal direction of this association is less clear. Distance and contact frequency may both depend on common factors such as the quality of the relationship or the needs of parents and children to have contact (Silverstein 1995). For that reason, distance can be regarded as a parallel dependent variable rather than as antermediating variable. We note that information on distance was only asked for the mother. Hence, in cases of a parental divorce, we do not know the distance to the father. Additional analyses indicate that the average travel time of nonresident children to their mother has not changed between the two survey years in any of the countries. ${ }^{3}$ Hence, we believe that omitting distance (i.e., travel time) from the model will not affect our conclusions about trends.

\subsection{Design}

We present models separately for four outcome variables: face-to-face contact with the mother, other contact with the mother, face-to-face contact with the father, and

\footnotetext{
${ }^{3}$ Travel time was measured with eight categories, ranging from $<2$ min to more than 5 h. These categories were recoded to the approximate middle points of the categories. Subsequently, the natural logarithm was taken since the variable is highly skewed. $T$-tests for year differences were -1.30 $(p=.19)$ for Germany, $-.20(p=.84)$ for Great Britain, $.51(p=.61)$ for the USA, $.88(p=.38)$ for Austria, and $-1.23(p=.22)$ for Italy.
} 
other contact with the father. Because we have several models for each of the four outcome variables, it is undoable to present the full results for each of the countries separately. For this reason, we start with an overall picture of change, using analyses that are based on the five countries combined. These models include dummy-variables for each country and thereby control for differences between countries in the average number of contacts. The results of these models are weighted so that each country-year combination contributes the same number of cases to the total sample. ${ }^{4}$ In the second set of analyses, we present results in a condensed format for each country separately.

For each outcome, we estimate three models. Model 1 includes a dummy-variable for the year of the survey $(0=1986,1=2001)$, next to the country-specific dummyvariables. This allows us to assess whether contact has changed in this group of western societies. This model includes respondents who are living with their parents and assigns these respondents to the category of daily contact. Model 2 excludes these respondents and focuses only on contact between parents and nonresident children. By comparing the results of Model 1 and 2, we can examine to what extent changes in contact are due to changes in coresidence. In Model 3, we add the independent variables and we assess what happens with the effect of year. A decline in the effect means that compositional changes can explain (part of) the trend. A remaining effect of year means that there have been behavioral changes after controlling for compositional changes. ${ }^{5}$ Note that Model 1 is not estimated for other contact since other forms of contact do not apply to resident children. Models for face-to-face contact are presented in Table 2, models for other contact are presented in Table 3.

In the second set of analyses, we present a regression decomposition in which we assess which variables have contributed to the trends. To explain this, we use the example of educational change. We first calculate the difference in mean education between the two years. This difference is equal to the effect of year on education. We subsequently multiply this difference by the effect of education on contact (as presented in Tables 2 and 3). Using the logic of direct and indirect effects, it becomes clear that the resulting multiplication is equal to the indirect effect of year on contact via education. Hence, this shows us the compositional effect of education on change in contact. Some compositional effects can be negative whereas others can be positive. A negative compositional effect means that a change has had a downward effect on contact over time, a positive effect means that a change has had an upward effect on contact over time. Even if there is no overall trend, compositional effects can play a role since upward and downward compositional effects can work against each other. Our regression decomposition is similar to the method developed by Oaxaca (1973). ${ }^{6}$

\footnotetext{
${ }^{4}$ This means that the overall trend will not be affected by differentially changing sample sizes in the different countries.

5 For contacts with fathers, the remaining effect can also be due to divorce (an unmeasured compositional change), as explained above.

6 The Oaxaca method multiplies the differences in the means of the $X$-variables with two different (sets of) regression coefficients: one which is based on the regression model for the first group (in our case 1986), and one which is based on the regression model for the second group (in our case 2001). Our method simply uses the average of these two sets of regression coefficients since there is no substantive consideration for favoring either one of the two.
} 
In the last set of analyses, we estimate all models for each country separately and we test whether trend effects are significantly different in the different countries. To facilitate the interpretation of these analyses, we only present net trend effects and we abstain from presenting the effects of the other independent variables.

\section{Results}

In Fig. 1, we present the percentages of children who had (at least) weekly contact with their father and mother (for the pooled 1986 and 2001 surveys). We do this separately for face-to-face contact and for other contact. We see that weekly contact is fairly common in most countries. In West Germany, Austria and Great Britain, about $60-70 \%$ of the children have at least weekly face-to-face contact with their mother. The percentages for fathers in these countries are a bit lower. Face-to-face contact with mothers is most common in Italy (85\%), as earlier studies have found, and least common in the United States (54\%). Greater distances between parents and children in the United States will presumably explain this. Other contact (mostly telephone contact) is not less frequent in the United States. An interesting observation is that country differences in other contact are smaller than differences in face-to-face contact. The country differences for fathers are similar as the country differences for mothers. However, we also see that the gap between the United States and the middle three countries (West Germany, Austria, and Great Britain) is larger for fathers than it is for mothers. In the United States, only $43 \%$ of the children have weekly face-to-face contact with their father. This is the lowest percentage in the figure. The reason is probably the high level of divorce in the United States.

An assumption behind most of our hypotheses is that there were compositional changes in the population between 1985 and 2001. To examine the validity of this assumption, we present means of the independent variables for each of the two years (Table 1). All trends are as expected: the relative number of women with paid work has increased, the level of education has increased, the number of siblings has declined, church attendance has declined, and the proportion of married people has declined. These changes confirm the underlying assumptions of our compositional hypotheses.

\subsection{Regression Results for the Pooled Countries}

The regression results for face-to-face contact are presented in Table 2. Table 2 shows that there is a significant decline in face-to-face contact with the mother. The magnitude of the decline is $13 \%$ (i.e., $e^{-.14}-1$ ). The result is only found for the sample which includes coresident children (Model 1). In the model without coresident children (Model 2), there is no significant change in face-to-face contact with the mother. The interpretation of these differences is that the initial decline in contact is fully due to the decreasing number of adult children who live with their parents. When covariates are added in Model 3, the trend becomes positive and 

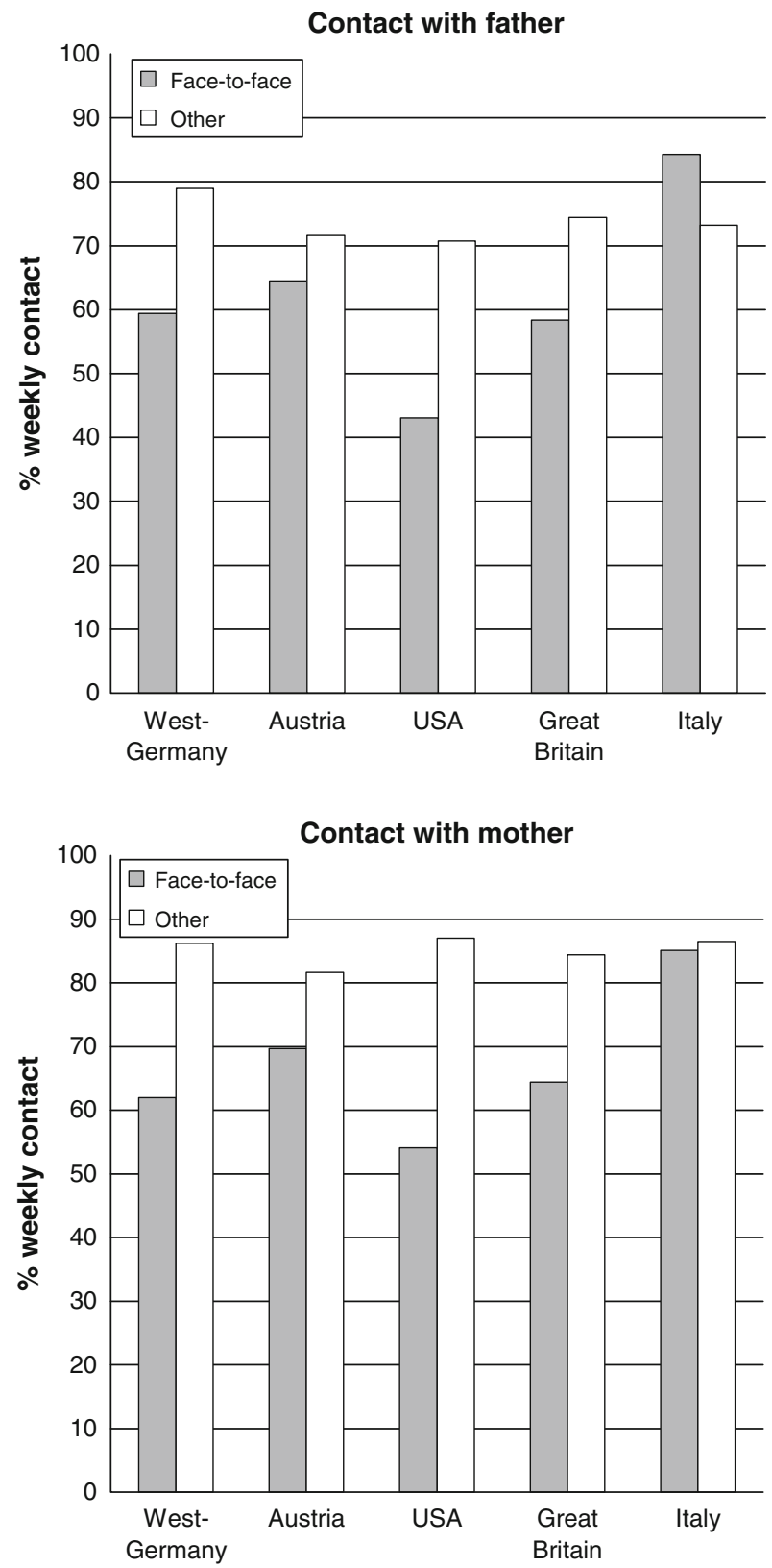

Fig. 1 Percentage weekly contact with father and mother by country and type of contact in the 19872001 period

significant. This shows that there has in fact been an increase in face-to-face contact, but this increase is suppressed by compositional changes. The net trend effect of .10 corresponds to an increase of $11 \%$, which is a modest change. 
Table 1 Descriptive statistics of independent variables and $t$ tests for differences in means between years

\begin{tabular}{|c|c|c|c|c|c|c|c|c|}
\hline & \multirow[t]{2}{*}{1986} & \multirow[t]{2}{*}{2001} & \multicolumn{6}{|c|}{$T$ test for difference between years } \\
\hline & & & $\begin{array}{l}\text { All } \\
\text { countries }\end{array}$ & $\begin{array}{l}\text { West- } \\
\text { Germany }\end{array}$ & $\begin{array}{l}\text { Great- } \\
\text { Britain }\end{array}$ & $\begin{array}{l}\text { United } \\
\text { States }\end{array}$ & Austria & Italy \\
\hline $\begin{array}{l}\text { Number of siblings } \\
\text { (child) }\end{array}$ & 2.31 & 2.08 & $5.64 *$ & -.02 & -.16 & $-.21 *$ & $-.18^{*}$ & $-.54 *$ \\
\hline Age of child & 38 & 39 & $-5.99^{*}$ & $1.72 *$ & $1.40^{*}$ & $1.64 *$ & $1.65^{*}$ & 1.80 \\
\hline $\begin{array}{l}\text { Education in years } \\
\text { (child) }\end{array}$ & 11.18 & 12.24 & $-12.62 *$ & $1.23^{*}$ & $1.46^{*}$ & $.40 *$ & 1.08 & $1.14^{*}$ \\
\hline $\begin{array}{l}\text { Attends church } \\
\text { frequently (child) }\end{array}$ & .31 & .23 & $7.04 *$ & $-.05^{*}$ & $-.07 *$ & $-.14^{*}$ & $-.07 *$ & $-.07 *$ \\
\hline Child is married & .79 & .68 & $10.49 *$ & $-.12 *$ & $-.13^{*}$ & $-.18 *$ & $-.16^{*}$ & .00 \\
\hline $\begin{array}{l}\text { Having a job } \\
\quad \text { (child, only women) }\end{array}$ & .49 & .67 & $-10.38 *$ & $.20 *$ & $.19 *$ & $.10 *$ & $.11 *$ & $.28 *$ \\
\hline $\begin{array}{l}\text { Having a job } \\
\text { (child, only men) }\end{array}$ & .90 & .85 & $3.83 *$ & .03 & $-.10^{*}$ & $-.09 *$ & $-.06^{*}$ & -.02 \\
\hline $\begin{array}{l}\text { Sex }(0=\text { female } \\
\quad 1=\text { male })\end{array}$ & .48 & .46 & $1.01 *$ & .02 & -.04 & .00 & -.02 & -.02 \\
\hline$N$ (unweighted) & 3693 & 2393 & & & & & & \\
\hline
\end{tabular}

$* p<.05$

Model 3 in Table 2 also shows the effects of the covariates. We see, in line with other studies, that higher educated persons have less frequent face-to-face contact with their mother than lower educated persons. In line with our hypothesis, it appears that children who often go to church have more frequent contact with their mother than other children. Sibsize also has a very clear effect: The more siblings the child has, the less frequent contact the child has with the mother. This too is in line with the earlier literature and with our hypothesis. The role of employment is considered in combination with gender. Men are coded 1 (and women 0) which implies that the main effect of employment in Model 3 refers to women. We do not find that working women have less frequent contact with their mother than nonworking women. This refutes the hypothesis although we note that the finding is consistent with earlier studies. Finally, we see that children do not have contact with their mother more often when they are single. This is also in contrast to our hypothesis.

In the last three columns of Table 2, we present the results for face-to-face contact with fathers. We observe a significant negative trend effect in the full sample, which amounts to a $27 \%$ decline in contact with fathers (Model 1). At first, this seems a substantial change. When leaving out coresident children (Model 2), the effect becomes smaller (11\%), although it is still negative and almost significant $(p<.10)$. Hence, a large part of the decline in contact with fathers is due to the decline in parent-child coresidence. When we add covariates to the model (Model 3 ), the trend disappears. In other words, the decline in contact among nonresident children is fully due to compositional changes. The compositional effect is therefore similar to the compositional effect found for mothers. In both cases, compositional 
Table 2 Regression of face-to-face contact: unstandardized regression coefficients

\begin{tabular}{|c|c|c|c|c|c|c|}
\hline & \multicolumn{3}{|l|}{ Mothers } & \multicolumn{3}{|l|}{ Fathers } \\
\hline & Model 1 & Model 2 & Model 3 & Model 1 & Model 2 & Model 3 \\
\hline Year 2001 (vs. 1986) & $-.14 *$ & .02 & $.10^{*}$ & $-.31 *$ & -.11 & -.02 \\
\hline Number of siblings of child & & & $-.11 *$ & & & $-.09 *$ \\
\hline Child's church attendance & & & $.26^{*}$ & & & $.35^{*}$ \\
\hline Child's education in years & & & $-.07 *$ & & & $-.06^{*}$ \\
\hline Child married (vs. single) & & & .04 & & & $.23 *$ \\
\hline Child paid work & & & .13 & & & .10 \\
\hline Paid work * male & & & .00 & & & .14 \\
\hline Mother is a widow & & & .04 & & & $-.20 *$ \\
\hline \multicolumn{7}{|l|}{ Child's age (vs. 30-39) } \\
\hline Under 30 & & & $.27 *$ & & & $.17^{*}$ \\
\hline $40-49$ & & & $-.18 *$ & & & -.10 \\
\hline 50 or older & & & $-.45^{*}$ & & & -.15 \\
\hline \multicolumn{7}{|l|}{ Country (vs. West Germany) } \\
\hline Great Britain & -.05 & $-.14 *$ & -.04 & $-.18 *$ & $-.26 *$ & $-.18^{*}$ \\
\hline United States & -.38 & $-.33^{*}$ & $-.16^{*}$ & $-.67 *$ & $-.54 *$ & $-.40^{*}$ \\
\hline Austria & $.35^{*}$ & .09 & .11 & $.36^{*}$ & .05 & .06 \\
\hline Italy & $1.02 *$ & $.74^{*}$ & $.83^{*}$ & $1.13^{*}$ & $.81 *$ & $.80^{*}$ \\
\hline Child male (vs. female) & & & -.18 & & & -.12 \\
\hline Constant & $3.99^{*}$ & $3.54 *$ & $4.39^{*}$ & $3.91 *$ & $3.39 *$ & $3.87^{*}$ \\
\hline$N$ & 6891 & 5569 & 5569 & 5099 & 4125 & 4125 \\
\hline$R$-squared & .078 & .050 & .095 & .114 & .072 & .102 \\
\hline
\end{tabular}

Note: Model 1 is with resident children, other models are without resident children

$* p<.05$

changes lead to a decline in contact over time. However, in the case of fathers, compositional changes explain a decline in contact whereas in the case of mothers, compositional changes suppress an increase in contact.

Effects of the other covariates on face-to-face contact with fathers are largely similar to the effects we found for face-to-face contact with mothers. A few exceptions are notable. For fathers, we find negative effects of widowhood. Children of widowed fathers less often have contact with fathers than children of married fathers. This finding is consistent with earlier studies and has usually been interpreted in terms of the kin keeping role of women (Rosenthal 1985). When fathers become widowers, they not only lose a spouse, they also lose someone who arranges the visits with the children. We note that the category of divorced fathers cannot be singled out in the data. Most divorced fathers will be in the non-widowed category. Another difference lies in the effect of marriage. Married children have more frequent contact with fathers than single children. For contact with mothers, we found no difference.

The trends for other contact with mothers are presented in Table 3. Other contact is mostly telephone contact, but in 2001 , it also includes email contact. We see a 
Table 3 Regression of other contact: unstandardized regression coefficients

\begin{tabular}{|c|c|c|c|c|}
\hline & \multicolumn{2}{|l|}{ Mothers } & \multicolumn{2}{|l|}{ Fathers } \\
\hline & Model 2 & Model 3 & Model 2 & Model 3 \\
\hline Year 2001 (vs. 1986) & $.26^{*}$ & $.20^{*}$ & $.15^{*}$ & .10 \\
\hline Number of siblings of child & & $-.13 *$ & & $-.13 *$ \\
\hline Child's church attendance & & .06 & & $.18^{*}$ \\
\hline Child's education in years & & $.03 *$ & & $.04 *$ \\
\hline Child married (vs. single) & & -.06 & & $.17 *$ \\
\hline Child paid work & & .05 & & .12 \\
\hline Paid work $*$ male & & -.09 & & .04 \\
\hline Mother is a widow & & .11 & & $-.40^{*}$ \\
\hline \multicolumn{5}{|l|}{ Child's age (vs. 30-39) } \\
\hline Under 30 & & $.20^{*}$ & & .06 \\
\hline $40-49$ & & .01 & & .07 \\
\hline 50 or older & & $-.30 *$ & & .12 \\
\hline \multicolumn{5}{|l|}{ Country (vs. West Germany) } \\
\hline Great Britain & $-.22 *$ & $-.21 *$ & $-.32 *$ & $-.34 *$ \\
\hline United States & -.11 & -.12 & $-.40 *$ & $-.44 *$ \\
\hline Austria & $-.18^{*}$ & $-.17^{*}$ & $-.27 *$ & $-.24^{*}$ \\
\hline Italy & $.35^{*}$ & $.41 *$ & .13 & .02 \\
\hline Child male (vs. female) & & $-.48 *$ & & -.24 \\
\hline Constant & $3.92 *$ & $4.09 *$ & $3.54 *$ & $3.21 *$ \\
\hline$N$ & 5509 & 5509 & 4107 & 4107 \\
\hline$R$-squared & .023 & .081 & .016 & .048 \\
\hline
\end{tabular}

Note: Model 1 is with resident children, other models are without resident children

$* p<.05$

strong increase in other contact with the mother. Changes are substantial: a $30 \%$ increase. Note that these results apply to the sample which excludes coresident children. When we compare Model 2 and 3, we observe that the trend becomes somewhat smaller. In other words, compositional changes have a small effect on changes in other contact with mothers. The net trend that remains is substantial (a $22 \%$ increase). The trend for other contact with fathers, presented in Table 3, is weaker. On average, other contact with fathers has increased with $16 \%$. After controlling for compositional changes, the trend in other contact with fathers is not significant anymore. Compositional changes do not play a very large role for other contact with fathers either but since the initial effect was modest, the net effect is just not significant anymore.

Effects of the other covariates in Table 3 show that other contact is somewhat less sensitive to social and demographic characteristics than face-to-face contact (cf. Van Gaalen and Dykstra 2006). Education has a small positive effect on contact, which is in line with other research. The lower level of face-to-face contact among the higher educated is apparently compensated in part by a higher level of other (mostly telephone) contact. This is in line with our hypothesis. Nonetheless, the 
Table 4 Decomposition of changes in contact with nonresident children

\begin{tabular}{|c|c|c|c|c|}
\hline & \multicolumn{2}{|l|}{ Mother } & \multicolumn{2}{|l|}{ Father } \\
\hline & $\begin{array}{l}\text { Face-to-face } \\
\text { contact }\end{array}$ & $\begin{array}{l}\text { Other } \\
\text { contact }\end{array}$ & $\begin{array}{l}\text { Face-to-face } \\
\text { contact }\end{array}$ & $\begin{array}{l}\text { Other } \\
\text { contact }\end{array}$ \\
\hline Change 1986-2001 & .015 & .261 & -.113 & .148 \\
\hline Net change & .096 & .204 & -.016 & .104 \\
\hline $\begin{array}{l}\text { Change due to composition } \\
\text { of which due to change in: }\end{array}$ & -.081 & .057 & -.097 & .045 \\
\hline Sex & .003 & .008 & -.003 & -.005 \\
\hline Age & -.022 & -.014 & -.015 & -.001 \\
\hline Sibsize & .025 & .029 & .018 & .026 \\
\hline Church attendance & -.020 & -.005 & -.031 & -.015 \\
\hline Education & -.069 & .032 & -.058 & .040 \\
\hline Marital status child & -.005 & .007 & -.022 & -.017 \\
\hline $\begin{array}{l}\text { Employment (gender } \\
\text { specific) }\end{array}$ & .008 & .007 & .010 & .010 \\
\hline Marital status parent & -.002 & -.007 & .003 & .005 \\
\hline
\end{tabular}

Note: Based on Model 2

effect on face-to-face contact is stronger (in an absolute sense) than the effect on other contact, showing that the compensation by telephone contact among the higher educated is not complete. We also see that other contact is less frequent in larger families. This effect is similar in size as it was for face-to-face contact. Church attendance has no significant effect on other contact with the mother, but it is associated with an increase in the level of other contact with the father. An important difference lies in the effects of gender. In line with what is known from other research, we find that women have more frequent other contact with the mother than men. ${ }^{7}$ The gender difference is not present for other contact with the father. Hence, the mother-daughter tie stands out when we look at other (telephone) contact.

In the previous analyses, we have shown to what extent the covariates are responsible for explaining the trend. In Table 4, we show which variables have contributed to or suppressed the trend. We see that most compositional changes have led to a decline in face-to-face contact. The increase in education between the two years is the most important factor for face-to-face contact with both fathers and mothers. The higher educated less often have contact with the parents and there has been a considerable increase in education, leading to a decline in contact with parents. Declining church attendance is the second most important factor. Because the proportion of people who attend church frequently decreased and because frequent church attendance has a positive effect on contact, there has been a decline in parent-child contact. Both these findings are in line with our hypotheses. We also find factors which produced an increase in contact over time. Sibsize has had a

\footnotetext{
7 This applies to jobless men and women as well as to men and women with a job.
} 
positive effect on the trend. Because sibsize has declined and because sibsize has a negative effect on contact, this has resulted in an increase in contact over time. The negative compositional changes due to education and church attendance are apparently counterbalanced in part by the positive effect of declining sibsize, which has had an upward effect on the change in contact. The latter effect is weaker, however, than the former, leading to an overall negative effect of compositional changes.

There are two clear refutations. The rise in women's employment has had no effect on the trend and the declining number of married respondents has had no effect either. This was also to be expected, given that there were no significant cross-sectional effects of daughter's employment and son's and daughter's marital status. The result is nevertheless important. Especially the rising economic role of women has been linked to many important demographic changes, but according to our analyses, it has not been important for changes in intergenerational contact.

Table 4 also shows that the compositional effects for fathers and mothers are similar. In addition, we see that for other forms of contact there are rather modest compositional effects. This is in part due to the fact that these other contacts are less sensitive to social and demographic variables, as can also be seen when comparing the effects in Tables 2 and 3.

\subsection{Regression Results for the Separate Countries}

Are the trends different in the different countries? To answer this question, we estimate Model 3 again while including interactions of year and country. The other independent variables are also interacted with country. The results are presented in Table 5 for all the four forms of contact. We list only the (net) trend effects (as implied by the interactions). We test the difference in the year effects across countries using an $F$ test.

We first look at the trend for face-to-face contact with mothers. The pooled model in Table 3 revealed a small increase $(11 \%)$. The country-specific results in Table 5 show that the increase is stronger in the United States and Great Britain (32\% and 25\%). In Austria the increase is about average whereas in West Germany and Italy there was no change. The $F$ test for overall differences in the trends among countries is not significant.

Table 5 Implied changes for each country after compositional changes are taken into account

\begin{tabular}{cccccccr}
\hline & Overall trend & $F$-test & West-Germany & Great Britain & United States & Austria & Italy \\
\hline $\begin{array}{c}\text { Face-to-face } \\
\text { Mother }\end{array}$ & $.10^{*}$ & 1.73 & .02 & .22 & .28 & .09 & -.01 \\
Father & -.02 & .31 & -.05 & .03 & -.09 & .05 & .06 \\
$\begin{array}{c}\text { Other contact } \\
\text { Mother }\end{array}$ & $.20^{*}$ & $8.48^{* *}$ & -.08 & .63 & .20 & .02 & .42 \\
Father & $.10 \sim$ & $2.74^{*}$ & -.07 & .43 & -.07 & .15 & .22 \\
\hline
\end{tabular}

$* p<.05$ 
We now turn to changes in face-to-face contact with fathers. The pooled model revealed no change in contact. The country-specific results confirm this. In all countries, trend coefficients are small, except perhaps in the United States where we find a modest decline in contact (9\%). Differences between countries in the trend effects are not significant.

The results for other contact with the mother reveal significant differences in the trends. The pooled model showed an increase in other contact (Table 4). The country-specific results show that these trends are stronger in Great Britain than elsewhere. The increase is also substantial in Italy and in the United States, but it is absent in the two German-speaking countries.

For other contact with the father, we found a small and insignificant increase in the pooled model (Table 4). Table 5 shows that three of the countries experienced an increase (Austria, Italy, and Great Britain), whereas West Germany and the United States experienced a small decline (7\%).

\section{Conclusion}

This paper is one of the first attempts to describe recent trends in the degree to which parents and adult children have contact with each other. In the literature, there is much speculation about the possible erosion of family ties in an era of individualism. This would coincide with changes in the conjugal family. Marriage has become more fragile, spouses have become less dependent on each other for their well-being, and there has been a general increase in the need for autonomy and individual development. Traditional family values have become weaker as well and this also applies to the normative obligations that children feel toward parents.

In contrast to all these speculations, we find no evidence for a decline. More specifically, our analyses show that when the focus is on face-to-face contact, there is a modest increase in contact with the mother and no change in contact with the father. Country-specific analyses suggest that the increase in face-to-face contact with the mother was stronger in the United States and in Great Britain. When focusing on other contact, we see a substantial increase in contact, although more so with the mother than with the father. Country-specific analyses suggest that these increases in other contact occurred primarily in the United States, Great Britain, and Italy.

These results apply to trends after compositional changes are taken into account. Compositional changes have played a somewhat complex role in these developments. In most countries, the overall result of compositional change has been a decrease in the level of contact. Especially important here are the expansion of education and the decline in church attendance, which have had downward pressures on intergenerational contact. There have also been opposing forces, especially the declining number of siblings, which had an upward pressure on intergenerational contact. The downward pressures are stronger, however, than the upward pressures. The increasing number of women who work for pay-often quoted as a vital trend for intergenerational relations - and the decreasing number of children who are married have had no effect on the trend. The consequences of these 
forces have been different for fathers and mothers. For mothers, these forces have hidden a true increase in contact, whereas for fathers, these changes are able to fully explain the initially observed decline in contact. We note that for fathers, divorce is an important omitted variable. Had we been able to include parental divorce, and had we added this to the compositional variables, the net change may have been an increase in contact, just as was observed for mothers. For the United States, where we now observe a small decline in contact with the father, the net decline may have been explained away, leading to net stability.

Our general conclusion is that there is no evidence for an erosion of intergenerational contact since the mid-1980s. Although changes in the composition of the population have indeed had a tendency to decrease contact over time, this is counterbalanced by other compositional changes (i.e., declining sibsize) and by behavioral changes. Is there then more evidence for an increase in the importance of intergenerational ties, as other authors have suggested? The answer is mixed.

First of all, for other forms of contact (not face-to-face), there indeed is evidence for an increase. However, this may have less to do with the nature of family ties since other forms of contact will probably have increased for nonfamily relationships as well. Due to the rapid diffusion of mobile phones and email facilities at home, we can speculate that other forms of contact have increased considerably for all types of relationships. Hence, we do not think that this trend reveals anything specific about the parent-child tie.

Second, there are signs of an increase in face-to-face contact, but only in two of the five countries (Great Britain and the United States). We discussed several possible reasons for an increase in contact. Life expectancy has increased, which means that parents and children will spend a larger part of their life together. In addition, due to declining fertility, children have become scarce, which may have increased the value of children in society. Finally, grandparents have become more important in their role as carer for their grandchildren, and this too may have strengthened the parent-child tie. Although these factors may all have played a role, it is not so clear why they would have played a greater role in Great Britain and the United States than in the other three countries we analyzed. We think that further speculation on this issue needs to be postponed until evidence of trends is accumulated in a larger number of countries.

Open Access This article is distributed under the terms of the Creative Commons Attribution Noncommercial License which permits any noncommercial use, distribution, and reproduction in any medium, provided the original author(s) and source are credited.

\section{References}

Aquilino, W. S. (1994). Impact of family disruption on young adult's relationships with parents. Journal of Marriage and the Family, 56, 295-313.

Bengtson, V. L. (2001). Beyond the nuclear family: The increasing importance of multigenerational relationships in American society. Journal of Marriage and Family, 63, 1-16.

Bengtson, V. L., Biblarz, T., \& Roberts, R. E. L. (2002). How families still matter: A longitudinal study of youth in two generations. Cambridge, UK: Cambridge University Press. 
Blossfeld, H.-P. (Ed.). (1995). The new role of women: Family formation in modern societies. Boulder: Westview Press.

Bonvalet, C. (2003). The local family circle. Population (English Selection), 58(1), 9-42.

Börsch-Supan, A., Hank, K., \& Jürges, H. (2005). A new comprehensive and international view on ageing: The survey of health, ageing and retirement in Europe. Mannheim: University of Mannheim.

Burr, J. A., \& Mutchler, J. E. (1999). Race and ethnic variation in norms of filial responsibility among older persons. Journal of Marriage and the Family, 61(3), 674-687.

Cherlin, A. J. (1992). Marriage, divorce, remarriage: Revised and enlarged edition. Cambridge, Mass: Harvard University Press.

Cooney, T. M., \& Uhlenberg, P. (1990). The role of divorce in men's relations with their adult children after mid-life. Journal of Marriage and the Family, 52, 677-688.

Daatland, S. O., \& Herlofson, K. (2003). Families and welfare states: Substitution or complementarity. In A. Lowenstein \& J. Ogg (Eds.), Oasis: Old age and autonomy-The role of service systems and intergenerational family solidarity. The final report (pp. 281-305). Haifa: University of Haifa.

De Graaf, P. M., \& Fokkema, T. (2007). Contacts between divorced and non-divorced parents and their adult children in the Netherlands: An investment perspective. European Sociological Review, 23(2), 263-277.

Gans, D., \& Silverstein, M. (2006). Norms of filial responsibility for aging parents across time and generations. Journal of Marriage and Family, 68, 961-976.

Grundy, E. (2000). Co-residence of mid-life children with their elderly parents in England and Wales: Changes between 1981 and 1991. Population Studies, 54, 193-206.

Grundy, E. (2005). Reciprocity in relationships: Socio-economic and health influences on intergenerational exchanges between third age parents and their adult children in great Britain. British Journal of Sociology, 56(2), 233-255.

Grundy, E., \& Shelton, N. (2001). Contact between adult children and their parents in Great Britain. Environment and Planning A, 33, 685-697.

Hagestad, G. O. (1986). The family: Women and grandparents as kinkeepers. In A. Pifer \& L. Bronte (Eds.), Our aging society: Paradox and promise. New York: Norton.

Höllinger, F., \& Haller, M. (1990). Kinship and social networks in modern societies: A cross-cultural comparison among seven nations. European Sociological Review, 6(2), 103-124.

Kalmijn, M. (2006). Educational inequality and family relationships: Influences on contact and proximity. European Sociological Review, 22(1), 1-16.

Kalmijn, M. (2008). The effects of separation and divorce on parent-child relationships in ten European countries. In C. Saraceno (Ed.), Families, ageing and social policy: Intergenerational solidarity in European welfare states (pp. 170-193). Cheltenham: Edward Elgar.

Kalmijn, M., \& Dykstra, P. (2006). Differentials in face-to-face contact between parents and their grown-up children. In P. A. Dykstra, M. Kalmijn, T. C. M. Knijn, A. E. Komter, A. C. Liefbroer, \& C. H. Mulder (Eds.), Family solidarity in the Netherlands (pp. 63-88). Amsterdam: Dutch University Press.

Kalmijn, M., \& Saraceno, C. (2008). A comparative perspective on intergenerational support: Responsiveness to parental needs in individualistic and familialistic countries. European Societies, 10(3), 479-508.

Killian, T., \& Ganong, L. H. (2002). Ideology, context, and obligations to assist older persons. Journal of Marriage and Family, 64, 1080-1088.

Klein Ikkink, K., Van Tilburg, T., \& Knipscheer, K. C. P. M. (1999). Perceived instrumental support exchanges in relationships between elderly parents and their adult children: Normative and structural explanations. Journal of Marriage and the Family, 4, 831-844.

Lawton, L., Silverstein, M., \& Bengtson, V. (1994). Affection, social contact, and geographic distance between adult children and their parents. Journal of Marriage and the Family, 56, 57-68.

Lesthaeghe, R. (1983). A century of demographic and cultural change in western Europe: An exploration of underlying dimensions. Population and Development Review, 9, 411-435.

Lesthaeghe, R., \& Meekers, D. (1986). Value changes and the dimensions of familialism in the European community. European Journal of Population, 2, 225-268.

Lye, D. (1996). Adult child-parents relationships. Annual Review of Sociology, 22, 79-102.

Murphy, M. (2004). Models of kinship from the developed world. In S. Harper (Ed.), Families in ageing societies (pp. 31-54). Oxford: Oxford University Press.

Oaxaca, R. (1973). Male-female wage differentials in urban labor markets. International Economic Review, 14(3), 693-709. 
Oppelaar, J., \& Dykstra, P. A. (2005). Contacts between grandparents and grandchildren. Netherlands Journal of Social Sciences, 40(2), 91-113.

Reher, D. S. (1998). Family ties in western Europe: Persistent contrasts. Population and Development Review, 24, 203-234.

Rosenthal, C. J. (1985). Kinkeeping in the familial division of labor. Journal of Marriage and the Family, 47, 965-974.

Rossi, A. S., \& Rossi, P. H. (1990). Of human bonding: Parent-child relations across the life course. New York: Aldine de Gruyter.

Ruggles, S. (2007). The decline in intergenerational coresidence in the United States, 1850-2000. American Sociological Review, 72, 964-989.

Sarkisian, N., \& Gerstel, N. (2008). Till marriage do us part: Adult children's relationships with their parents. Journal of Marriage and Family, 70(2), 360-376.

Shelton, N., \& Grundy, E. (2000). Proximity of adult children to their parents in Great Britain. International Journal of Population Geography, 6, 181-195.

Silverstein, M. (1995). Stability and change in temporal distance between the elderly and their children. Demography, 32(1), 29-46.

Silverstein, M., \& Bengtson, V. L. (1994). Does intergenerational social support influence the psychological well-being of older parents? The contingencies of declining health and widowhood. Social Science and Medicine, 38(7), 943-957.

Silverstein, M., \& Bengtson, V. L. (1997). Intergenerational solidarity and the structure of adult childparent relationships in American families. American Journal of Sociology, 103, 429-460.

Silverstein, M., \& Marenco, A. (2001). How Americans enact the grandparent role across the family life course. Journal of Family Issues, 22(4), 493-522.

Silverstein, M., Parrott, T. M., \& Bengtson, V. L. (1995). Factors that predispose middle-aged sons and daughters to provide social support to older parents. Journal of Marriage and the Family, 57(2), $465-475$.

Spitze, G., \& Logan, J. (1989). Gender differences in family support: Is there a payoff? The Gerontologist, 29(1), 108-113.

Spitze, G., \& Logan, J. R. (1991). Sibling structure and intergenerational relations. Journal of Marriage and the Family, 53, 871-884.

Stein, C. H., Wemmerus, V. A., Ward, M., Gaines, E., Freeberg, A. L., \& Jewell, T. C. (1998). 'Because they're my parents': An intergenerational study of felt obligation and parental caregiving. Journal of Marriage and Family, 60(3), 611-623.

Szydlik, M. (1996). Parent-child relations in East and West Germany shortly after the fall of the wall. International Journal of Sociology and Social Policy, 16(12), 63-87.

Thornton, A., \& Young-DeMarco, L. (2001). Four decades of trends in attitudes toward family issues in the united states. Journal of Marriage and the Family, 63, 1009-1037.

Tomassini, C., Glaser, K., Wolf, D. A., Broese van Groenou, M. I., \& Grundy, E. (2004a). Living arrangements among older people: An overview of trends in Europe and the USA. Population Trends, 115, 24-34.

Tomassini, C., Kalogirou, S., Grundy, E., Fokkema, T., Martikainen, P., Broese van Groenou, M., et al. (2004b). Contacts between elderly parents and their children in four European countries: Current patterns and future prospects. European Journal of Ageing, 1, 54-63.

Van de Kaa, D. J. (1987). Europe's second demographic transition. Population Bulletin, 42, 1-59.

Van der Pas, S., Van Tilburg, T., \& Knipscheer, K. (Eds.). (2007). Changes in contact and support within intergenerational relationships in the Netherlands: A cohort and time-sequential perspective. Interpersonal Relations Across the Life Course, Advances in Life Course Research, 12, 243-274.

Van Gaalen, R. I., \& Dykstra, P. A. (2006). Solidarity and conflicts between adult children and parents: A latent class approach. Journal of Marriage and Family, 68(4), 947-960.

Vanderleyden, L., \& Vandenboer, L. (2003). Ouderen en de tweede demografische transitie. Bevolking en Gezin, 32(1), 45-64.

Vollenwyder, N., Bickel, J.-F., Lalive d-Epinay, C., \& Maystre, C. (2002). The elderly and their families, 1979-94: Changing networks and relationships. Current Sociology, 50(2), 263-280.

Waite, L., \& Harrison, S. C. (1992). Keeping in touch: How women in mid-life allocate social contacts among kith and kin. Social Forces, 70, 637-655.

Wolf, D. A. (1995). Changes in the living arrangements of older women: An international study. The Gerontologist, 35(6), 724-731. 